This journal provides immediate open access to its content under the Creative Commons BY 4.0 license. Authors who publish with this journal retain all copyrights and agree to the terms of the above-mentioned CC BY 4.0 license

DOI: $10.2478 /$ seeur-2020-0008

\title{
THE IMPACT OF THE COVID-19 PANDEMIC ON DOMESTIC VIOLENCE-PSYCHOLOGICAL CONSEQUENCES, THE LEGAL FRAMEWORK AND ITS TREATMENT IN THE REPUBLIC OF NORTH MACEDONIA
}

\author{
Adj. Asst. Prof. Hatixhe Islami \\ Faculty of Contemporary Social Sciences, South East European University, North Macedonia, \\ h.islami@seeu.edu.mk \\ Asst. Prof. Arta Selmani-Bakiu \\ Faculty of Law, South East European University, North Macedonia, \\ arta.selmani@seeu.edu.mk \\ Assoc. Prof. Emine Zendeli \\ Faculty of Law, South East European University, North Macedonia, \\ e.zendeli@seeu.edu.mk \\ Asst. Prof. Sami Mehmeti \\ Faculty of Law, South East European University, North Macedonia, \\ s.memeti@seeu.edu.mk
}

\begin{abstract}
In this paper the authors present the psychological consequences of social isolation on domestic violence during the Covid-19 pandemic as well as the legal framework in the RNM on addressing the phenomenon of domestic violence. In this age of globalization and drive for material conformity, family life is quite difficult to cope with. This "war" for material comfort during the pandemic, has strained and stressed many families as a result of the created circumstances. Public safety measures, including physical distance and social isolation, which
\end{abstract}


have also been implemented in the RNM have contributed in making family problems even more pronounced. Social distance and staying at home are very effective in reducing the transmission of Covid-19 virus, but these safeguards disrupt the routines of spouses and families. Domestic violence affects a large number of families, and it is estimated that in times of social isolation, all forms of violence have been inflicted against family members regardless of their gender and age. The most common forms of domestic violence during Covid-19 pandemic in our country are psychological, physical and economic violence. Some countries affected by Covid-19 have seen increases in levels of domestic violence, including violence against children, violence against partners, and violence against the elderly. This paper presents the results of research conducted which highlight the fact that during the Covid-19 pandemic, there has been an increase in levels of domestic violence in the Republic of North Macedonia in the first six months of 2020. The authors give their recommendations on the need for action by state institutions during the Covid-19 pandemic in order to adapt methods and circumstances towards the protection of victims of domestic violence.

Keywords: domestic violence, psychological consequences of social isolation, legal framework

\section{INTRODUCTION}

Family is one of the fundamental and most important communities that make up society. Given that the human is born, lives and creates diverse relationships within the context of family, it is undeniable that family has the most important role in shaping his/her personality. In this sense, the first life experiences, education, upbringing and the psychophysical and intellectual development of children are realized in the framework of the family. Family and social values, pedagogical habits, and worldviews on good and bad social phenomena are acquired precisely in the family circle. (Zendeli, Selmani-Bakiu, Mickoviq, Ristov, 2020, p.91).

As an institution of family law "the family is the natural and fundamental group unit of society and is entitled to protection by society and the State" (Article 16 para. 3 of the UDHR, 1948), while the household is and should be the safest place for family members. But today in the world there are many individuals who, while fighting for their rights in the marriage, put their personal rights above the rights that should belong to the family (Miliša, 2014, p.144).

When it comes to the family, the issue of violence that happens within it is often raised. Throughout history, domestic violence has been considered a purely personal problem, while today it has become a social problem (Ajduković, 2000, p.109-114). In situations where the 
home becomes a place of conflict and dispute, there is an imbalance in family relations, which leads to the loss of security guaranteed by national laws as well as international treaties.

Good treatment, education of family members, courtesy, caring for family members, are basic elements for the harmonious functioning of a family. In cases when a common language can not be found for the solution of eventual problems within the family, or when the situation escalates and violence is exercised as a "solution" of the same, we witness an excess of any normal limits of the functioning of the family.

Domestic violence, as well as violence in the framework of the social circle, today is recognized as a general socio-political problem. Domestic violence is a phenomenon on which many articles have been written; many legal, social and psychological discussions and debates have been opened; international conventions and national laws have been adopted; and although it continues to be treated as a problem in all aspects, it has still not been eradicated as a family, political, social and psychological problem. Also, special attention has been paid to domestic violence by state institutions, non-governmental organizations, but which have not managed to raise awareness among citizens about the occurrence of this phenomenon, which constantly increases the number of victims of domestic violence.

The Covid-19 pandemic has brought many economic, legal, social and family problems, not only in the Republic of North Macedonia but also in many other countries of the world. In addition to health risks, it has potentially contributed to the increased risk of domestic violence, as well as child abuse and neglect. Numerous data show that the rate of domestic violence has increased significantly in the Balkan countries since the imposition of restrictions on movement in the fight against Covid-19 (Balkaninsight, 2020).

Some countries affected by Covid-19 have experienced increases in levels of domestic violence, including violence against children, partner violence and violence against the elderly, as evidenced by the World Health Organization (World Health Organization, 2020).

During the imposition of measures to prevent infection with the Covid-19 virus, psychological well-being and physical security have been at risk for society as a whole. Among them was the risk of a major threat to the well-being and lives of victims of domestic violence. In places where there were isolation measures and restrictions on movement during the pandemic, cases of domestic violence have been reported. Due to safety measures, family members have been confined to the same space with the perpetrators of violence, and most have been denied access to appropriate assistance. Getting out of the house, going back and forth from work, school, 
which at least made it easier for the victims to get out of the house, were unavailable during the isolation. In addition, many victims are afraid to make contact with institutions or providers of assistance for victims of domestic violence, because of the risk that the perpetrator will hear or see them. The fear of reporting a case of violence is not evident only during the pandemic, but it is a phenomenon that constantly increases the number of victims of domestic violence, precisely because of the cases of domestic abuse that go unreported. This tense situation of isolation is likely to increase the domestic violence is also confirmed by World Health Organization, which states that "stress, the disruption of social and protective networks, loss of income and decreased access to services all can exacerbate the risk of violence for women" (World Health Organization, 2020).

It is evident that during the time of isolation and pandemic in general, family problems have intensified even more, which can also be taken as an indication of some violent actions between family members. Through their research, the authors come to obvious conclusions that domestic violence is significantly increases in situations of social stress, psychological pressures and financial insecurity. In addition to the many highlighted problems, one should also look at the good side of the Covid-19 pandemic, which in functional families has had some positive impacts, especially in terms of closeness between members of the nuclear family. This situation has softened the individualism that humans have today. During the days in isolation, parents had more time to deal with obligations towards their children, which they overlooked due to their preoccupation with employment and career pursuits.

Preventive measures against the spread of Covid-19 virus are still active in many countries. According to the results of research conducted with parents of children aged 1-12 years, during the first stages of implementation of these measures, $83 \%$ of parents reported that due to school closures and isolation at home they are more engaged in many activities with their children, compared to the period before Covid-19 (Hyseni-Duraku, Jahiu,Geci, 2020, p.2 from Lee, 2020). This increased engagement in activities with their children is reported to have made parents feel closer to them; however, $50 \%$ of parents also reported that isolation and physical distance affected their parenting. Moreover, $61 \%$ of parents reported having intensified disciplinary styles during this period, using verbal punishment and physical violence with their children (Hyseni-Duraku, Jahiu,Geci, p.2, from Lee, 2020).

Violence against women tends to increase in any emergency, including epidemics. Stress, the breakdown of social and protective networks, increasing economic hardship, and reduced 
access to services can exacerbate women's risk of suffering from violence. The paper also makes a significant contribution in terms of information on the legal framework for the treatment of domestic violence in the Republic of North Macedonia and the preventive and protective measures undertaken by state institutions and NGOs to protect potential victims of domestic violence.

\section{THE SITUATION CREATED IN THE FAMILY AND SOCIETY DURING THE COVID-19 PANDEMIC: AN INCREASE OF DOMESTIC VIOLENCE}

Human behavior is one of the most important factors that dictate the severity of pandemics both for the spread of the virus and for the psychological effects it causes, such as isolation, anxiety, and insecurity. With the emergence of the Covid-19 virus the world is facing a global public health crisis. The social isolation that is still present to varying degrees worries not only mental health professionals but also many professionals in various fields. Public safety measures, including physical distance and social isolation, that have been implemented in the RNM have triggered further the family problems. Multiple restrictions have been placed on public movement to prevent the spread of the virus. Especially social isolation has proved dangerous for a substantial part of families since the risk of domestic violence was possible. Isolation from the Covid-19 virus has created extraordinary circumstances that have changed almost all aspects of social life. The current situation requires us not to leave the residence, except when necessary, and to avoid physical contact with other people, in order to protect ourselves, the people we love and the community.

Domestic violence is one of the most troubling problems during the days of isolation. The National Network to End Violence against Women and Domestic Violence in North Macedonia stressed that the Covid-19 crisis could increase the number of cases of domestic violence. "The Covid-19 phenomenon has changed the course and the way of life. It has brought married couples closer, made them face to face within 24 hours with a few small breaks when one or the other goes out of the house to be supplied with the necessary things, but in general their contact is very congested and this cause sparks of intolerance to appear between them. In turn it creates a turbulent environment or atmosphere that escalates into uncontrolled violence" (Helsinki Committee for Human Rights, 2020).

Public safety measures also have led to the emergence of a confusing situation in the social aspect. The perspective of social confusion is an important theory that applies to those who 
have different needs and face little or no means of social support, whether formal or informal. According to Alaggia et al. (2009 p.335-341) the perspective of social confusion highlights the obstacles faced by women, more specifically, the insufficient institutional responses to violence perpetrated against women of different backgrounds. According to Ptacek (1999), as a result of these inadequate responses, abused women tend to withdraw within themselves and internalize guilt towards themselves and stay with their abusive partners (Alaggia et al., 2009, p. 340).

To date, no research and studies have been conducted in the RNM on analyzing the impact of social isolation on domestic violence and the psychological consequences that isolation reflects. As reported by studies in other countries the magnitude of the risk associated with social isolation is comparable to biomedical and psychosocial risk factors. However, our understanding as a society of how and why social isolation is dangerous to health - or vice versa - and why social ties and relationships are protective of health remains very limited. (James S. House, 2001, p. 273-274).

It should be noted that in the RNM there are professional teams that can help cases of domestic violence, but social, police and medical services are still not visited in a timely manner and sufficiently by victims of domestic violence. Victims of violence should know that seeking psycho-social support from the right services increases the longevity of their mental effectiveness. Data from the Counselor for Prevention and Protection from Domestic Violence at the Ministry of Labor and Social Policy proves that during the Covid-19 pandemic there is an increase in domestic violence in the first six months of 2020 , even by $7.3 \%$ compared to 2019, especially in the second quarter of 2020 when more cases of domestic violence have been reported. During the pandemic, the most obvious forms of domestic violence are as follows: psychological violence, physical violence and economic violence (Sterjov, 2020). Most cases are combined forms of psychological and physical violence, but there are cases where all three forms of domestic violence dominate. The largest number of applications submitted to the Centers for Social Work in RNM are closed with the adoption of a temporary protection measure: mandatory visit to a counseling center for perpetrators of domestic violence, which is in accordance with the Regulation on the manner of execution of the imposed temporary protection measure - mandatory visit to a counseling center for perpetrators of domestic violence (Sterjov, 2020).

\section{The impact of social isolation on domestic violence}


Social isolation is a state of complete lack of contact between an individual and society. Loneliness and social isolation are significantly associated with incidental insanity (Kuiper et al., 2015, p.39-57). Social isolation has similar characteristics both in temporary cases and for those with a historical cycle of lifelong isolation. All types of social isolation can include staying home for long periods of time, lack of communication with family, acquaintances or friends. Lack of constant human contact can also cause conflict with friends with whom the isolated person may occasionally talk, or cause problems with family members. True social isolation over years and decades can be a chronic condition that affects all aspects of a person's existence. Social isolation can lead to feelings of loneliness, fear of others, or negative selfesteem. Social isolation may be related to behavioral changes, including an unhealthy lifestyle such as: smoking, alcohol, lower physical activity, inadequate diet (Kobayashi and Steptoe, 2018, p. 582-592).

Social isolation as a state of lack of contact differs from loneliness, which reflects temporary and involuntary lack of contact with other people in the world. Social isolation can be an issue for individuals of any age, although symptoms may vary by age group. (Khullar, Bhruv, 2016, p.12-22).

NGOs report increasing domestic violence during the months of isolation as a result of the Covid-19 pandemic, largely dictated by living under one roof with perpetrators. Organizations focused on the protection of women and girls also express concern that isolation has increased pressure and further exacerbated the situation of former victims of violence in Albania. Civil society organizations report increased domestic violence due to isolation during the two months of the pandemic, while expressing concern that the emergency situation forced most victims to suffer in silence. (Reporter.al, 2020).

At risk of violence are also families in which there has been no violence before, but fears of job insecurity and financial problems have increased the opportunities for domestic conflicts. During the Covid-19 pandemic, which represents a stressful situation at the global and local level, the question arises as to what extent the home is a safe place for victims of domestic violence, especially women and children, who, due to the measures to protect them from the virus, they are actually even more at risk by staying with abusers at home (Vijesti.hr, 2020).

It is more than obvious that social isolation measures may be welcome for perpetrators of domestic violence because they use isolation as a means to control their victim. (World Health Organization, 2020). 
Violence is an element of abuse which, among other actions, aims to intimidate, humiliate, and control the victim. The distinction becomes even clearer if the term "abuse" is exchanged with the term "intimate terrorism", implying its systemic character as a means of domination, control and degradation (Rohrbaugh, 2006, p. 292).

Strategies that address the root causes of violence can be relatively effective in preventing violence, albeit mental and physical health and individual responses, personalities, and so on, have always been crucial factors in shaping these behaviors (World Health Organization, 2020).

\section{Psychological consequences of social isolation during the Covid-19 pandemic}

The psychological consequences of isolation, which are still present to varying degrees, worry mental health professionals. Being indoors with the inability to get out, with the awareness that it is even more dangerous outside, that anyone can endanger us with infection as well as the uncertainty of how long it will all last, is a troubling challenge. Fear, stress and sadness as well as boredom are normal responses to an "abnormal" situation.

Domestic violence during pandemics is associated with a number of economic and psychosocial factors. Stress arises from a combination of environmental and individual conditions, characteristics that are important for resolving the current situation. According to Pearlin (1989, p. 241-256) stress is a function of the distribution of social resources, as well as the position and role of individuals in society. Lack of social resources increases the likelihood of other stressful events occurring or increases the intensity of existing stresses (for ex. divorce can lead to deterioration of financial situation, which conditions the acceptance of employment in unfavorable conditions, which may affect the deterioration of relationships with children and problems in child behavior).

The Covid-19 pandemic can cause severe stress reactions for all people and some people may develop more pronounced reactions. Behavior towards stress can be different and the most common symptoms are of emotional, cognitive and physical nature, as well as difficulty sleeping, aggravation of chronic mental and physical illness and increasing use of alcohol and other psychoactive substances. To protect ourselves from stress it is very important not to let negative emotions lead us to fear and panic. Stress symptoms are a normal reaction in such situations and they are more likely to be more pronounced in people who hear, watch and read 
news about this disease, especially if the sources are uncertain and unverified and if they do not come from authorized professional organizations.

\section{DEFINITION OF DOMESTIC VIOLENCE AND THE LEGAL FRAMEWORK FOR ITS TREATMENT IN THE REPUBLIC OF NORTH MACEDONIA}

After the independence of the Republic of North Macedonia in 1991, important steps were taken towards the democratization of the country and the construction of a stable system for the protection of the fundamental rights and freedoms of its citizens. Until 2004, the issue of domestic violence was not regulated by law. Legally, the phenomenon of domestic violence in the Republic of North Macedonia was regulated in 2004, when amendments and supplements were adopted to the Law on Family (Official Gazette of the Republic of North Macedonia No. 33/2004.), Criminal Code (Official Gazette, No. 19. / 2004) and Law on Social Protection (Official Gazette of the Republic of North Macedonia No. 65/2004.) through which domestic violence received institutional treatment. The abovementioned novelties provided two systems for legal protection: Criminal and Civil ones.

In no case should the legal remedies provided (civil and criminal) for protection be applied to the detriment of one, respectively the other. According to their content and above all the purpose for which they are intended, these systems are complementary and only in that sense should they be implemented.

Thus, in the RNM, domestic violence was first defined in the context of the amendments to the Criminal Code of 2004 when within its general part the definition of domestic violence was given: "Family violence shall refer to abuse, rude insults, safety threats, inflicting physical injuries, sexual or other mental and physical violence which causes a feeling of insecurity, threat or fear towards a spouse, parents or children or other persons who live in a marriage or unwed partnership or other joint household, as well as towards a former spouse or persons who have a child together or have close personal relations (Article 122, para. 21 of the Criminal Code). By the very definition of the term domestic violence, the position that the RNM legislation had before the establishment of the Criminal Code, according to which domestic violence is a problem of the family, is abandoned. This means that domestic violence is a state problem and the state is the one that must take all measures and parameters to successfully deal with the problem of domestic violence. The incrimination of this phenomenon was not realized through the establishment of a specific criminal offense that would be entitled "Domestic 
Violence", but this was done by anticipating aggravating circumstances for existing criminal offenses that contain elements of domestic violence, including psychological, physical and sexual violence. Although in the Criminal Code domestic violence is not provided as a separate criminal offense, in some of its provisions the legislator nevertheless punishes more harshly the cases when violent acts are committed during the exercise of domestic violence, or considers the fact that violent acts are committed within family as an aggravating circumstance.

Also, the issue of domestic violence has been partially included in the Law on Family with its amendments in 2004, which provided several types of protection measures to help victims of domestic violence is systematized in a separate chapter of this law. Its provisions prohibit all forms of violence between family members, regardless of gender and age.

Domestic violence is often used as a synonym for intimate partner violence, which is perpetrated by a spouse or partner in an intimate relationship against another spouse or partner and can occur in heterosexual or same-sex relationships, or between ex-spouses or partners. In its broadest sense, domestic violence also includes violence against children, parents or the elderly. It takes a number of forms, including physical, verbal, emotional, economic, religious, reproductive, and sexual abuse, which can range from subtle, coercive to marital rape, and violent physical abuse such as killing, beatings, mutilation of women's genitals, and acid shedding resulting in disfigurement or death. Globally, victims of domestic violence are mostly women, and women tend to experience more severe forms of violence.

It should be noted that with the amendments to the Law on Social Protection, a new service for victims of domestic violence was brought - temporary accommodation for victims in the Center for Victims of Domestic Violence and the so-called "Shelters".

Despite the changes in the criminal legislation regarding the needs of treatment of victims of domestic violence in the criminal-material, criminal-procedural and victimological standpoint as well as the effect of assistance and protection measures provided by the Family Law regarding aspects of family protection for these victims, it was still not sufficient to overcome the problem since the legal norm without an implementation mechanism remains unfeasible, therefore it was deemed necessary to issue a lex specialis. Thus, in 2014, the Government of the Republic of North Macedonia adopted the Law on Prevention, Combating and Protection from Domestic Violence. In 2015, the Government of the Republic of North Macedonia adopted a decision on the formation of the National Coordination Body against Domestic Violence (Official Gazette, no. 72. 2015). 
In addition to the existing legislation, the Ministry of Labor and Social Policy has adopted special regulations for the implementation and monitoring of measures for the protection of victims of domestic violence, including: the Regulation on the manner of implementation and monitoring of the measures for protection of the victim of domestic violence undertaken by the center for social work and on the manner of monitoring the temporary protection measures as well as the Regulation on the manner of execution of the temporary measure for protection mandatory visit to a counseling center for perpetrators of domestic violence. These regulations serve the Centers for Social Work in taking measures towards both victims and perpetrators of domestic violence. The first regulation serves to undertake all measures for protection from domestic violence starting from the implementation and monitoring of measures for protection of the victim of domestic violence, monitoring of temporary measures for protection from domestic violence imposed by the court, as well as by the center's professionals, psycho-social assistance to the victim of domestic violence and protection in other forms in order to prevent future domestic violence (Article 2).

The second regulation pays special attention to the measures to be taken against perpetrators of domestic violence. This regulation prescribes the manner of execution of the temporary measure for protection - mandatory visit to counselling centers for perpetrators of domestic violence within the program for psycho-social treatment. It should be noted that this measure was most evident during the Covid-19 pandemic. The follow-up measure of counselors aims to improve the behavior of the perpetrator of domestic violence through some training and psycho-social measures that would affect the action and behavior of the perpetrator of domestic violence in the future. These programs aim at the perpetrator of domestic violence to learn social skills which will affect him / her to change his / her violent behavior and to start respecting the values that bring peace and love in family relationships (Article 2).

The Ministry of Labor and Social Policy of the RNM has also approved the policy framework related to the activities that need to be undertaken against domestic violence. Legal and political measures include several stages and processes of development of various activities in the fight against domestic violence. In this regard, several measures have already been taken by this Ministry: preparation of protocols for dealing with cases of domestic violence; unification of the civil and criminal system; unified and positive practices in combating domestic violence.

It is also important to emphasize the international instruments and conventions that refer to domestic violence. Relevant international bodies and entities such as the European Court of 
Human Rights, the Committee on Human Rights, the Committee on the Convention on the Elimination of All Forms of Discrimination against Women and the Committee against Torture have proved that the indirect implementation of the International Convention on Civil and Political Rights, the European Convention on Human Rights, the Convention on the Elimination of All Forms of Discrimination against Women, have obliged states, in accordance with international law, to prevent the violation of human rights in private and public life and to commit to their protection and advancement by establishing adequate legislation and relevant mechanisms for its implementation.

In addition to many international documents and initiatives, it is worth mentioning the Convention on the Elimination of All Forms of Discrimination against Women of 1979, which claims to protect women from all forms of discrimination, according to which: "Discrimination against women means distinction, exclusion or restriction made on the basis of sex which has the effect or purpose of impairing or nullifying the recognition, enjoyment or exercise by women, irrespective of their marital status, on a basis of equality of men and women, of human rights and fundamental freedoms in the political, economic, social, cultural, civil or any other field." (article 1, Convention on the Elimination of All Forms of Discrimination against Women).

In December 2017, the Parliament of the Republic of North Macedonia ratified the "Istanbul Convention" on preventing and combating violence against women and domestic violence. This convention is the most advanced international treaty to address domestic violence as a serious violation of human rights. The convention aims to ensure zero tolerance for this type of violence and is a major step forward in making Europe safer. Prevention of violence, protection of its victims and prosecution of perpetrators are the cornerstones of this convention. It also aims to change the mindsets of individuals by calling on members of society, especially men and boys, to change behaviors. In essence, the Convention is a new call for equality between men and women, as violence against women is deeply rooted in social inequality and has been going on due to a culture of intolerance and denial (Istanbul Convention, 2011). Ratification and implementation of this convention has, among other things, resulted in the amendment of several laws, including the Law on Prevention, Combating and Protection from Domestic Violence, the Law on Equal Opportunities for Women and Men, the Law on Prevention and Protection from discrimination, the Family Law and the Law on Child Protection. 
Given the restrictive measures that are being adopted globally for protection against the Covid19 virus which increases the risk of domestic violence, the Office of the United Nations High Commissioner for Human Rights has called on all governments to respect the rights of women and children and find urgent measures to protect victims of domestic violence (OHCR, 2020).

\section{Law on Prevention, Combating and Protection from Domestic Violence}

As mentioned above, the Law on Prevention, Combating and Protection from Domestic Violence is a lex specialis which regulates in detail any legal action in terms of taking legal and social measures for the victims of domestic violence. The law very clearly defines domestic violence as any ill-treatment, insult, endangerment of safety, physical harm, sexual or other physical, psychological or economic violence that causes a feeling of insecurity, threat or fear towards: a spouse, a parent, children or other persons living in a marital or extramarital union or living in a joint household, as well as the ex-spouse or persons who have joint children or have close personal relations.

The following are defined as state authorities who must be in direct control of domestic violence: the Ministry of Labor and Social Policy; Ministry of Internal Affairs, Ministry of Health; The Ministry of Education and Science, the Ministry of Justice, local government units, institutions that carry out activities within the scope of social protection, child protection, internal affairs, health, employment and education. All the institutions above need to take measures to protect victims as well as to protect against and prevent violence in the family.

All these institutions must implement concrete measures towards the prevention of domestic violence within the scope of their competencies provided by this Law. In addition to the numerous preventive measures provided by law, it is important to emphasize the protective measures which are mainly implemented by the Centers for Social Work. The Centers for Social Work undertake a series of protective measures towards victims of domestic violence, including: placing the victim of domestic violence in the Center for Social Work; health protection; necessary psycho-social intervention and treatment; psycho-social treatment in counseling; assistance to families for the continuous education of the child; legal aid and representation; economic assistance to the victim through her involvement in the labor market.

In addition to many protective measures towards victims of domestic violence, the Law provides for a number of interim measures that may be imposed on perpetrators of violence: prohibition to threaten to commit domestic violence; prohibition to mistreat, harass, call, 
contact or otherwise communicate with a family member, directly or indirectly; prohibition to approach at a distance of less than 100 meters to the place of residence, school, place of work or certain place which is regularly visited by another family member; eviction regardless of ownership; prohibition to possess a firearm or other weapon; obligatorily return of the items that are necessary to meet the daily needs of the family; compulsory legal maintenance of the family; compulsorily attendance of counseling; compulsory treatment of the perpetrator, if he abuses alcohol, drugs and other psychotropic substances or has a mental illness; reimbursement of medical expenses and other expenses caused by domestic violence and imposition of any other measure that the court deems necessary to guarantee the safety and well-being of other family members.

\section{MEASURES TAKEN BY INSTITUTIONS FOR PROTECTION FROM DOMESTIC VIOLENCE DURING THE COVID-19 PANDEMIC}

Based on the constitutional commitments for the protection of fundamental human rights and freedoms and respect for the generally accepted norms of international law for the elimination of all forms of discrimination against women, including domestic violence, the Government of the RNM during the state of emergency has provided full coordination regarding the prevention of the spread of the Covid-19 virus, also taking all necessary measures to protect victims of domestic violence. To this end, the Ministry of Labor and Social Policy, in cooperation with the OSCE Mission in Skopje, prepared a campaign for the prevention and protection from domestic violence in the state of emergency due to Covid-19 through which victims of domestic violence and the general public were informed of all forms of domestic violence, where to go and apply for help and what are the existing services for the protection of victims of domestic violence. The Ministry of Labor and Social Policy through this campaign has encouraged victims of domestic violence, but also all citizens who are witnesses or have knowledge of violence, to report it to SOS lines free of charge for victims of domestic violence; the nearest police station; the Center for Social Work; health institutions; so that professionals can protect victims from perpetrators of domestic violence (Ministry of Labour and Social Policy, 2020).

The Ministry of Labor and Social Policy in cooperation with the OSCE Mission has also provided 658 food packages to support those affected by the Covid-19 pandemic, of which 329 packages have been distributed to victims of domestic violence. The distribution of these 
packages was done through the Red Cross and the Centers for Social Work (Ministry of Labour and Social Policy, 2020).

Starting with the first of May 2020, the Civil Society Strengthening Platform has started its third year of the EU/UN Women programme 'Implementing norms, changing minds'. The EU/UN Women programme 'Implementing norms, changing minds' aims at ending genderbased discrimination and violence against women in the Western Balkans and Turkey, with a particular focus on the most disadvantaged groups of women. To better respond to the needs of women victims of violence and to ensure adequate support as well as taking into consideration the fear of resurgence of Covid-19 cases, Civil Society Strengthening Platform partners in Albania, Bosnia and Herzegovina, Kosovo, Montenegro, North Macedonia, Serbia and Turkey have prepared a set of guidelines in all national languages to better support national governments and service providers in times of crisis (National Network to end Violence Against Women and Domestic Violence, 2020).

Home is not always a safe place for women and their children, and they are especially at-risk during lockdown, as they cannot escape their abusers. A grave concern is that social distancing and confinement rules imposed by national governments have triggered additional risks of domestic violence. In order to provide support and help to women and children victims of domestic violence, National Network established three services which provided telephone and online support: counseling and support by social worker, counseling and support by psychologist and counseling and support by legal advisor. These services were established in March 2020. The experience of National network to end violence against women and domestic violence is in line with these statements (Ibidem, 2020).

National Network to End VAW and DV prepared and sent several documents to the Government, relevant ministries and the media related to adopted measures for Covid-19: Request for amending the decision for prohibition of movement of citizens over the entire territory of the country; Request for issuing urgent measures for protection of women and children of domestic violence during state of emergency; Protocol on Health Care and Safe Housing for Victims of Domestic Violence at Centers for the Victims of Domestic Violence (Shelters) and other centers providing housing services in the event of a health crisis or pandemic; Overview of urgent measures and steps for protection of women and children victims of domestic violence undertaken by the Government and competent intuitions. The present guidelines are to remind and support the national government and service providers in 
Republic of North Macedonia, to better respond to the needs of women and their children, girls' victims of violence to the effects of the lockdown measures in light of the outbreak of the Covid-19 virus. These guidelines are to be applicable also after the lockdown measures are lifted. 


\section{CONCLUSION}

In the most general sense of the word, domestic violence is a combination of psychological, social and family factors that together create an atmosphere in which abuses occur in the form of physical, psychological, sexual, social, economic violence to the victims. Domestic violence is a serious social problem, because it affects the essential cell of society - the family.

Domestic violence is not specific to just one society. It is prevalent everywhere and only the causes of its action make it different. The causes of its occurrence are not always found in internal family, moral or psychological factors, but also in other social causes. There are several types of domestic violence that can be explained as a result of the influence of society at large, the habits and stress caused by the phenomena of unemployment, drugs, prostitution, trafficking and crime. Domestic violence does not spare any society, it is a public and not a private issue, and therefore it requires special attention from the whole society. The factors that can influence its appearance are numerous but the main cause of violence continues to be the unequal power that exists between couples.

The authors of this text conclude that the social impact of the Covid-19 pandemic has been widespread and highly challenging. No aspect of normal social functioning has been spared. Social isolation and distancing are necessary measures to prevent the spread of the virus, but they also lead to rising levels of loneliness and social isolation, which in turn produce consequences related to physical and mental health.

The paper also provides grounded evidence that measures of social isolation during the Covid19 pandemic cause fluctuations within the emotional and psychological well-being of individuals, and therefore, each individual should utilize cognitive or emotional skills to perform his or her function within the family and society. Utilizing certain skills helps prevent violence and helps build satisfying and mature relationships with family members, constructively facilitating adaptation to external conditions and internal conflicts.

The paper provides evidence that during the current Covid-19 prevention measures, psychological well-being and physical security are particularly at risk for the society and its normal functioning. As a result of these measures, women and children are currently forcibly imprisoned by perpetrators of violence, and many have been denied access to appropriate assistance. Leaving home, that is engaging in routine activities, is an opportunity for victims of violence to seek support for protection from domestic violence, but this opportunity is unavailable during social isolation. 
The authors during their research also come to the conclusion that social isolation and psychological consequences during the Covid-19 pandemic can severely affect the mental balance of the individual. Particularly at risk are people suffering from depression or anxiety disorders that are now in a state of possible deterioration of their condition. It is therefore very important to provide them with psycho-social support and support strategies to make them feel more social.

When observing the rules set by the authorities regarding the prevention of the virus, special attention should be paid to psychological health. The current health emergency situation due to the spread of the Covid-19, contains all the features of a potentially stressful situation. Psychological reactions from stress and the risk of infection are very likely to prevail to some degree.

Despite a rich national and international legal framework, and the numerous initiatives of NGOs and relevant institutions to provide assistance to victims of domestic violence, the facts show that there is no evidence of success in terms of action of legal and social measures. Victims continue to face the problem of being abused in their own home even during the Covid19 pandemic, and this is confirmed by the authors in the text, because the percentage of increase in domestic violence is evident.

The authors of this article propose that local self-government units in the area of prevention and deterrence of domestic violence should adapt to the circumstances during their action in times of pandemics in order to facilitate institutional access to victims of domestic violence in obtaining necessary legal aid assistance and psychological counseling. It is evident that the Centers for Social Work are not technically ready to act in these situations. They urgently need to provide online access for victims of domestic violence through electronic platforms (Skype, ZOOM, and Google Meet) as well as through local SOS hotline for provision of psychosocial assistance to victims of violence. Additionally they need to intensify their work at more specific schedules in order to provide the victims of domestic violence with legal protection all the while respecting the institutional and health measures.

Centers for Social Work should train their employees to act under the conditions in which the society has started to live in RNM. Regulations need to be amended and adapted in line with the current situation, which would provide victims easier access to the legal system to protect their violated rights. 
Also, local self-government units should take measures to establish mutual and coordinated cooperation at local or regional level between Centers for Social Work, police stations, health institutions, and civil associations in order to reduce the risk of domestic violence.

Legal clinics that are registered to provide free legal aid should develop a strategy for action regarding the provision of counseling and legal support to victims of domestic violence during the Covid-19 pandemic. Information and assistance of this nature are lacking in the RNM.

The message of the authors is that space and time must be found to strengthen family ties and values. We all need to remember how valuable all family members are to us and how important the family is. Quality family relationships should be cultivated and equated with mutual respect. Violence destroys family values and leaves the problems unresolved. 


\section{REFERENCES}

- Ajduković, M. (2000). Određenje i oblici nasilja u obitelji. Nasilje nad ženom u obitelji (pages 109-114). Zagreb: Društvo za psihološku pomoć.

- Alaggia, R., Regehr, C. \& Rishchynski, G. (2009). Intimate partner violence and immigration laws in Canada: How far have we come? International Journal of Law and Psychiatry. 32(6), pages, 335-341.

- Hyseni-Duraku, Z; Jahiu,G; Geci,D. (2020). Ndikimet e Covid-19, përvojat traumatike dhe sjelljet e fëmijëve në stresin prindëror, praktikat e prindërimit dhe ndryshimet në sjelljen e fëmijëve

- James S. House, Mjekësia Psikosomatike. (2001), Publication no. 2, Volume 63, pages 273274

- Kuiper, J. S. et al. (2015). Social relationships and risk of dementia: A systematic review and metaanalysis of longitudinal cohort studies. Ageing Research Reviews, 22, 39-57.

- Kobayashi, L. C. and Steptoe, A. (2018), Social Isolation, Loneliness, and Health Behaviors at Older Ages: Longitudinal Cohort Study. Annals of Behavioral Medicine, Volume 52, Issue 7, July 2018, Pages 582-593

- Khullar, B. "How Social Isolation Is Killing Us". The New York Times (2016)

- Miliša, Z. (2014) Šok današnjice. Osijek: Filozofski fakultet.

- Rohrbaugh, E. (2006). Domestic violence in same gender relationships. Family Court Review, 44 (2), 287-299

- Pearlin, L. I. (1989). The sociological study of stress. Journal of Health and Social Behavior, $30,241-256$

- Sterjov,L. Interview with Advisor for Prevention and Protection from Domestic ViolenceMinistry of Labour and Social Policy of Republic of North Macedonia, Semptember 2020

- Zendeli,E; Selmani-Bakiu,A; Mickoviq,D; Ristov.A; E drejta familjare, Tetovë, 2020

- Законот за превенција, спречување и заштита од семејно насилство (Official Gazette of RM, no.138/2014)

- Кривичен законик (Official Gazette of RM, no.37/1996)

- Закон за социјална заштита (Official Gazette of RM, no.79/2009)

- Правилник за начинот на спроведувањето и следењето на мерките за заштита на жртвата на семејно насилство преземени од центарот за социјална работа и за начинот на следење на изречените привремени мерки за заштита (Official Gazette of RM, no.17/2015)

- Правилник за начинот на извршувањето на изречената привремена мерка за заштитазадолжително посетување советувалиште за сторители на семејно насилство (Official Gazette of RM, no.17/2015)

- Convention on the Elimination of All Forms of Discrimination against Women (1979)

- Universal Declaration of Human Rights (1948)

- https://balkaninsight.com/2020/04/21/covid-19-dhe-dhuna-ne-familje-kur-shtepia-seshtevendi-me-i-sigurt/?lang=sq_Retrieved 2020-09-03

- http://www.slvesnik.com.mk/Issues/d9037c10167b46b4b91a9fc2cf7e3188.pdf\#page=49 Retrieved 2020-09-06 
- https://www.nytimes.com/2016/12/22/upshot/how-social-isolation-is-killing-us.html Retrieved 2020-09-20

- $\quad$ https://rm.coe.int/168064d3f6 Retrieved 2020-09-06

- http://www.mtsp.gov.mk/covid-19-ns_article-kako-da-se-zashtitime-od-semejno-nasilstvokade-da-pobarame-pomosh.nspx_ Retrieved 2020-09-11

- http://www.mtsp.gov.mk/covid-19-ns_article-mtsp-obezbedeni-658-paketi-so-hrana-za-zrtvina-semejno-nasilstvo.nspx Retrieved 2020-09-09

- http://www.mtsp.gov.mk/covid-19-ns_article-zrtvite-na-semejno-nasilstvo-covid19.nspx Retrieved 2020-09-11

- https://www.ohchr.org/EN/NewsEvents/Pages/DisplayNews.aspx?NewsID=25749\&LangID= E\&fbclid=IwAR2OBhZDtYFpipC_mbC5g7swdnYw63G6nvwNQpG0AeZHjrD6FfsfukpyCA (Retrieved 2020-08-20 https://www.glasprotivnasilstvo.org.mk/en/17-06-2020-cssp-guidelines-to-better-supportwomen-and-girls-victims-of-violence-throughout-the-covid-19-pandemic /Retrieved 202008-20

- http://www.glasprotivnasilstvo.org.mk/wp-content/uploads/2020/04/Barane-do-Vlada.pdf Retrieved 2020-08-21

- http://www.glasprotivnasilstvo.org.mk/wp-content/uploads/2020/05/urgent-measures-forprotection-of-women.ang.pdf Retrieved 2020-08-21

- http://www.glasprotivnasilstvo.org.mk/en/19-05-2020-overview-of-urgent-measures-andsteps-for-the-protection-of-women-and-children-victims-of-domestic-violence-undertakenby-the-competent-institutions/ Retrieved 2020-08-25

- https://www.who.int/emergencies/diseases/novel-coronavirus-2019/question-and-answershub/q-a-detail/violence-against-women-during-covid19?gclid=EAIaIQobChMIiJeW99796wIVk9eyCh13xgpTEAAYASAAEgKJG_D_BwE Retrieved 2020-09-22

- http://www.reporter.al/izolimi-gjate-pandemise-katalizator-i-dhunes-ndaj-grave-dhe-vajzave/ Retrieved 2020-08-02 https://vijesti.hrt.hr/599707/socijalna-izolacija-moze-dovesti-do-povecanja-nasilja-u-obitelji Retrieved 2020-08-02 